\title{
Impact of 10-valent pneumococcal conjugate (PCV 10) vaccination on incidence and mortality rates of pneumococcal meningitis in children under 5 in Brazil
}

\author{
Impacto da vacinação pneumocócica conjugada 10 valente (PCV 10) nas taxas de incidência e de \\ mortalidade por meningite pneumocócica em menores de cinco anos no Brasil
}

Impacto de la vacuna 10-valente neumocócica conjugada (PCV 10) sobre las tasas de incidencia y de mortalidad causadas por la meningitis neumocócica en niños menores de cinco años en Brasil

\author{
Mércia de França Nóbrega \\ ORCID: https://orcid.org/0000-0001-8016-4504 \\ Universidade Federal de Campina Grande, Brazil \\ E-mail: merciaufcg@gmail.com \\ Larissa Mercielly Nóbrega Medeiros \\ ORCID: https://orcid.org/0000-0002-1541-3911 \\ Centro Universitário de Patos, Brazil \\ E-mail: larissamedeiros@med.fiponline.edu.br \\ Marco Aurélio Palazzi Sáfadi \\ ORCID: https://orcid.org/0000-0002-4401-9446 \\ Faculdade de Ciências Médicas da Santa Casa de São Paulo, Brazil \\ E-mail:masafadi@uol.com.br
}

\begin{abstract}
The objective of this study was to assess the impact of 10-valent pneumococcal conjugate (PCV10) vaccination on the incidence and mortality of pneumococcal meningitis in children under 5 in Brazil. A descriptive ecological, populationbased quantitative study of secondary data from SINAN records for 2003-2009 and 2011-2017 and on vaccine coverage for 2011-2017 was conducted. The study was approved under permit CAAE 23629719.6.0000.5181. After PCV10 vaccine introduction, a substantial consistent reduction in incidence of and mortality rates of pneumococcal meningitis (70.33\% Northeast, $69.49 \%$ Southeast) was observed across all regions of Brazil. Although the Human Development Index (HDI) improved during the study period, lethality rates remained high (North $=34.45 \%$ pre versus $40.08 \%$ postvaccination), with no clear pattern of reduction associated with improved HDI in Brazil. In the final years of the study, a concerning decline in vaccination coverage rates was evident. Only the South (96.52\%) and Mid-West (96.17\%) regions attained the $\geq 95 \%$ vaccine coverage recommended by the Ministry of Health. This situation highlights the need for urgent measures to restore coverage rates and prevent recrudescence in cases and deaths associated with potentially preventable diseases.
\end{abstract}

Keywords: Vaccination coverage; Epidemiology; Meningitis, Pneumococcal; Mortality.

\section{Resumo}

O estudo objetivou avaliar o impacto da vacinação pneumocócica conjugada 10-valente (PCV10) sobre a incidência e a mortalidade por meningite pneumocócica em menores de 5 anos de idade no Brasil. Trata-se de um estudo ecológico, de base populacional e descritivo, por meio de dados secundários mediante uma abordagem quantitativa, através dos registros do SINAN nos períodos de 2003 a 2009 e 2011 a 2017 e a cobertura vacinal de 2011-2017. Parecer favorável, CAAE: 23629719.6.0000.5181. No período posterior à introdução da vacina PCV10 observou-se uma diminuição substancial das taxas de incidência e de mortalidade (redução na Região Nordeste 70,33\% e Região Sudeste 69,49\%), atribuídas à meningite pneumocócica, consistente em todas as regiões do País. Houve melhora do Índice de Desenvolvimento Humano durante o período do estudo, contudo, as taxas de letalidade se mantiveram elevadas (região Norte $34,45 \%$ para 40,08\%), sem uma tendência clara de diminuição correlacionada ao aumento do IDH no país como um todo. Nos últimos anos do estudo, evidenciou-se preocupante queda das taxas de cobertura vacinal. Apenas as Regiões Sul $(96,52 \%)$ e Centro-Oeste $(96,17 \%)$, conseguiram atingir a cobertura vacinal preconizada pelo Ministério da Saúde igual ou maior que $95 \%$. Destacando a necessidade de medidas urgentes de resgate destas coberturas para não ser observada recrudescência de casos e mortes associadas a doenças potencialmente preveníveis.

Palavras-chave: Cobertura vacinal; Epidemiologia; Meningite pneumocócica; Mortalidade.

\section{Resumen}

El estudio tuvo como objetivo evaluar el impacto que la vacunación neumocócica conjugada 10-valente (PCV10) tuvo sobre la incidencia y mortalidad por meningitis neumocócica en niños menores de 5 años en Brasil. Se trata de un 
estudio ecológico, con base poblacional y descriptivo, que utiliza datos secundarios por medio de un enfoque cuantitativo, a través de registros del SINAN durante los períodos que van de 2003 a 2009 y de 2011 a 2017 y de la cobertura de la vacunación en el período 2011-2017. Opinión favorable, CAAE: 23629719.6.0000.5181. En el período posterior a la introducción de la vacuna PCV10, hubo una reducción substancial (en la Región Nordeste de 70,33\% y en la Región Sudeste de 69,49\%) de las tasas de incidencia y mortalidad causadas por la meningitis neumocócica. Esta reducción fue consistente en todas las regiones del país. Hubo una mejora en el Índice de Desarrollo Humano durante el período de estudio, sin embargo, las tasas de letalidad se mantuvieron altas (Región Norte, de 34,45\% a 40,08\%), sin una clara tendencia a la baja en correlación con el aumento del IDH en el país en su conjunto. En los últimos años del estudio, se registró una caída preocupante de las tasas de la cobertura de vacunación. Solo en las Regiones Sur (96,52\%) y Centro-Oeste $(96,17 \%)$ se logró alcanzar la cobertura de vacunación recomendada por el Ministerio de la Salud, igual o superior al $95 \%$. Se destaca la necesidad de medidas urgentes para elevar el alcance de estas coberturas con el fin de evitar el recrudecimiento de los casos y muertes asociadas a enfermedades potencialmente prevenibles.

Palabras clave: Cobertura de vacunación; Epidemiología; Meningitis neumocócica; Mortalidad.

\section{Introduction}

Pneumococcal meningitis (PM) is associated with high morbidity and mortality in children worldwide, particularly in developing countries (Barichello, et al., 2012; Oliveira, 2017). Invasive diseases caused by pneumococcus, including meningitis, sepsis, and bacterial pneumonia, are responsible for approximately 800,000 deaths annually among children aged under 5 years (Grando, et al., 2015).

Pneumococcal meningitis continues to be a major public health burden, despite the dramatic impact of the introduction of the PCV10 vaccine in lowering the incidence rate of the disease. A study conducted in Mozambique between 2013 and 2015 by Nhantumbo et al. (2017) revealed a decline in the percentage of cases attributed to PM from $33.6 \%$ in 2013 to $1.9 \%$ in 2015 . Studies by Grando et al. (2015) and Vieira and Kuppek, (2016) showed a significant decrease in the incidence rates of PM after introduction of PCV-7 in Australia, Spain and the USA, among other countries.

Of the group of preventable diseases, PM has a high lethality rate, although this figure varies greatly for different countries. In New Zealand, IPD had a lethality rate of $1.96 \%$ in the under 5s age group in 2014 (Varghese, et al., 2018). In the decade 2000-2010, Streptococcus pneumoniae (Spn) was the leading cause of bacterial meningitis in Paraguay, associated with high lethality rates of $20 \%$ to $40 \%$ (Lovera, et al., 2011; Moreira, et al., 2016). In Brazil, the lethality rate was also high, reaching 30\% for pneumococcal meningitis between 2003 and 2018 (Moraes, et al., 2019).

The global mean infant mortality rate recorded in 2017 was 18 deaths per 1,000 live births (Omwono and Silundika, 2020). Also, Brazil was ranked 107th in the world for mortality rate of children under 5, recording 16 deaths for every 1,000 live births, behind Argentina, Uruguay and Chile (UNICEF, 2012). Nevertheless, one of the goals of the World Health Organization (WHO) is to reduce mortality in children under 5 to 25 deaths per 1,000 live births by 2030 (WHO, 2018).

The present study is justified for its epidemiological value, given surveys mapping the sociodemographic characteristics and particularities of each region of the country are required to plan public health actions, for the importance of preventive immunization. In this context, assessing the impact of PVC-10 introduction into the National Immunization Program (NIP) on rates of incidence and mortality of PM is vital because, although studies have investigated the early impact of vaccination, recent long-term data are lacking.

Therefore, the objective of this study was to assess the impact of 10-valent pneumococcal conjugate vaccination on the incidence and mortality rates of pneumococcal meningitis in children under 5 years in Brazil.

\section{Method}

A quantitative, descriptive, population-based, ecological study of secondary data was carried out. The ecological study drew on group data from official statistical bodies responsible for the information system covering the population of a country with continental proportions (Rouquayrol, 2013). 
The study was based on secondary data for information held on the Tabnet - Datasus system (Ministry of Health) from the Brazilian Disease Notification System (SINAN) on the incidence, lethality and mortality of pneumococcal meningitis in the population of under-5s, according to data catalogued by the Brazilian Institute of Geography and Statistics (IBGE) for the 2000 and 2010 census. All records for the period pre (2003-2009) and post (2011-2017) introduction of the PCV10 vaccine were assessed. Data for 2010, the year the vaccine was introduced in Brazil, were not included. Data on vaccine coverage between 2011 and 2017 in infants under 1 year of age were collected. Information on all regions in Brazil was collected for the two periods.

Brazil has five main regions divided into 26 Federal States plus the Federal District. In 2017, the overall Human Development Index (HDI) was around 0.754 (Chao et al., 2018). The estimated population of Brazil in 2017 was 207.7 million and population growth between 2016 and 2017 was $0.77 \%$ (IBGE, 2019).

Cases notified on the SINAN were identified and data on sociodemographic variables (age, region and state of residence), along with etiology and evolution (discharge/cure, deaths) were extracted from records. A database holding information on hospitalizations, incidence, lethality and mortality associated with PM for the periods pre and post-PCV10 vaccine was used.

Vaccine coverage by region in the age group studied after vaccine introduction was taken from the PNI/Data-sus page. The IBGE population statistics for the age group studied were used.

Data analysis was performed in two stages through descriptive and spatial statistics. Statistical analysis was performed using the software SPSS version 13.0.

The PM cases notified during P1 and P2 were described and calculations performed of incidence and mortality rates (per 100,000 population) for 2003-2009 (pre vaccine introduction) and for 2011-2017 (post vaccine introduction) and for lethality rates (per 100 population). Data for the year the vaccine was introduced in Brazil (2010) were not included in the analysis. The means of incidence and mortality for pre and post-vaccine periods were compared using Student's $t$-test.

Vaccination coverage rates were compiled from records held on the NIP information system (NIP, http://tabnet.datasus.gov.br/cgi/deftohtm.exe?pni/cnv/cpniuf.def ). The level of significance adopted for all tests was 5\%.

For the description of lethality due to pneumococcal meningitis in children aged five years or under by region, choropleth maps were produced for the periods pre (2003-2009) and post-vaccine (2011-2017), based on lethality rates x 100 (Brasil, 2007). The Microsoft Office Excel 2010 spreadsheet utility was used to calculate the indicators, the QGIS 2.18.10 software package was employed to build the thematic maps, while the TerraView 4.2.2 tool was used to calculate Moran's I statistic. The neighbors neighborhood matrix was adopted and a 5\% level of significance established. The base maps of Brazil were obtained from the IBGE via their Maps Portal. Choropleth maps were also produced on QGIS 2.18.10 to describe and analyze the Human Development Index (MHDI) by Brazilian region, drawing on 2000 and 2010 census data. The MHDI is a measure comprising income, education and longevity, divided into the categories very low (0-0.499), low (0.500-0.599), medium (0.600-0.699), high (0.700-0.799) and very high (0.800-1.0). MHDI data were collected from the Atlas of Human Development in Brazil (2013).

The study complied with the ethics principles set forth in Resolution n ${ }^{\circ} 580$, of 22 March, 2018, and was approved under permit CAAE nº 23629719.6.0000.5181 (Brasil, 2018).

\section{Results}

The number of notified cases of PM cases in children under 5 for all regions of Brazil during the pre-vaccine period P1 (2003-2009) and post-vaccine period - P2 (2011-2017) are depicted in Figure 1. A total 3,069 cases were notified during P1 and 1,130 during P2, excluding 2010 (335 cases). 
Distribution of cases by region was North (194), Northeast (582), Southeast (2,584), South (703) and Mid-West (297). Following the introduction of the PCV-10 vaccine, there was a steady decline in notified cases of PM, with the curve flattening from 2015 onwards. (Figure 1)

Figure 1 - Distribution of PM case notifications recorded on the Brazilian Disease Notification System (SINAM) for Brazil and regions, by year (2003-2017).

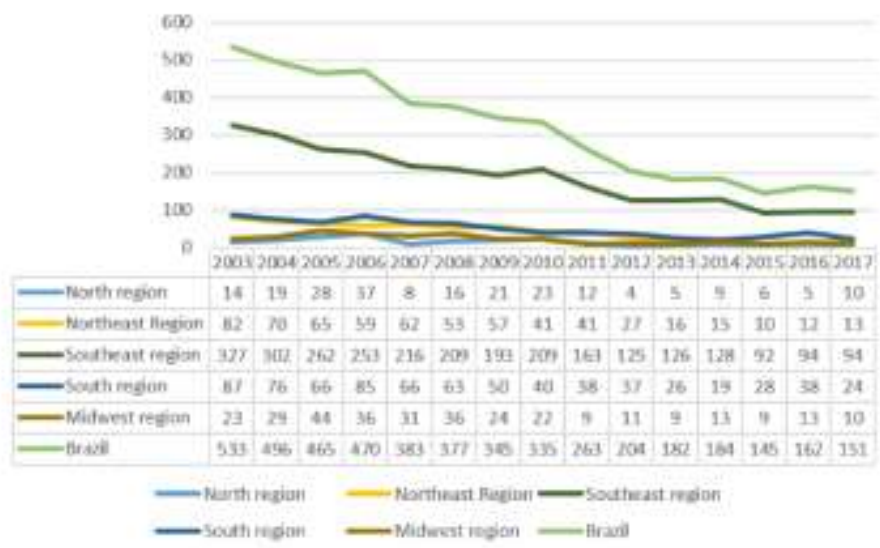

Source: Ministry of Health/Brazilian Disease Notification System - SINAN (2018).

The incidence rate of PM in children aged under 5 in Brazil decreased by $61.3 \%$ (p<0.001) between pre $(2003-2009)$ and post (2011-2017) vaccination periods (see Table 1). These reductions were significant for all regions analyzed: Mid-west (72.6\%), Northeast (68.4\%), South (66.4\%), North (74.1\%) and Southeast (59\%). (Table 1)

The comparison of spatial distribution of lethality rates of PM in under-5s for Brazil and regions with HDI using choropleth maps revealed a difference between P1 and P2 across all regions (Figure 2). Thus, a tendency for lower lethality with improved HDI can be seen between P1 and P2 in Northeast and Southeast regions. By contrast, increases in both HDI and lethality rates were observed in the Mid-West and North regions. In the South region, however, HDI improved without any accompanying significant increase in lethality rates.

Figure 2 - Choropleth maps showing spatial distribution of PM lethality rates in under-5s and HDI for Brazil and regions.

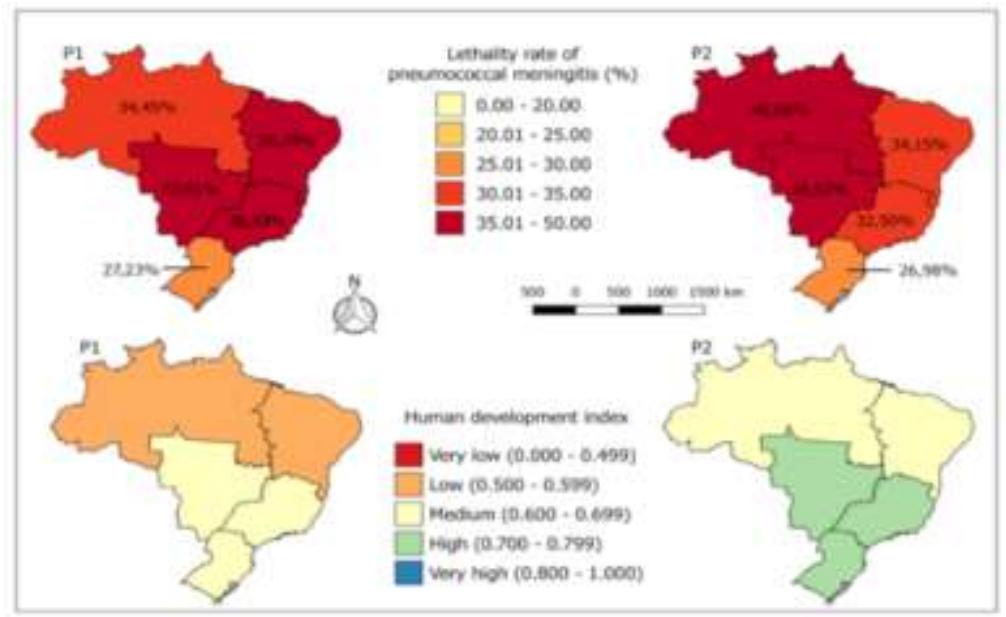


Source: Compiled by author based on study results. Brazilian Disease Notification System (SINAN/Ministry of Health).

Table 1 - Mean PM incidence rates in under-5s for Brazil and regions, pre (M1) and post (M2) PCV-10 vaccine introduction.

\begin{tabular}{|c|c|c|c|c|c|c|c|c|c|c|c|c|}
\hline \multicolumn{13}{|c|}{ GENERAL } \\
\hline \multirow[b]{2}{*}{ COMPARISON } & \multicolumn{2}{|c|}{ Mid-West } & \multicolumn{2}{|c|}{ Northeast } & \multicolumn{2}{|c|}{ North } & \multicolumn{2}{|c|}{ Southeast } & \multicolumn{2}{|c|}{ South } & \multicolumn{2}{|c|}{ Brazil } \\
\hline & $\begin{array}{l}2003- \\
2009\end{array}$ & $\begin{array}{l}2011- \\
2017\end{array}$ & $\begin{array}{l}2003- \\
2009\end{array}$ & $\begin{array}{l}2011 \\
2017\end{array}$ & $\begin{array}{l}2003- \\
2009\end{array}$ & $\begin{array}{l}2011- \\
2017\end{array}$ & $\begin{array}{l}2003- \\
2009\end{array}$ & $\begin{array}{l}2011- \\
2017\end{array}$ & $\begin{array}{l}2003- \\
2009\end{array}$ & $\begin{array}{l}2011- \\
2017\end{array}$ & $\begin{array}{l}2003- \\
2009\end{array}$ & $\begin{array}{l}2011- \\
2017\end{array}$ \\
\hline Mean & 2.81 & 0.77 & 1.27 & 0.40 & 1.48 & 0.38 & 4.66 & 1.91 & 4.49 & 1.51 & 3.00 & 1.16 \\
\hline SD & 0.64 & 0.11 & 0.29 & 0.24 & 0.96 & 0.19 & 1.87 & 0.47 & 1.59 & 0.37 & 0.93 & 0.26 \\
\hline $\begin{array}{c}\text { Difference = } \\
(\text { M1-M2 })\end{array}$ & \multicolumn{2}{|c|}{2.04} & \multicolumn{2}{|c|}{0.87} & \multicolumn{2}{|c|}{1.10} & \multicolumn{2}{|c|}{2.75} & \multicolumn{2}{|c|}{2.98} & \multicolumn{2}{|c|}{1.84} \\
\hline$\%$ Reduction & \multicolumn{2}{|c|}{72.6} & \multicolumn{2}{|c|}{68.4} & \multicolumn{2}{|c|}{74.1} & \multicolumn{2}{|c|}{59.0} & \multicolumn{2}{|c|}{66.4} & \multicolumn{2}{|c|}{61.3} \\
\hline p-value & \multicolumn{2}{|c|}{$<0.001$} & \multicolumn{2}{|c|}{$<0.001$} & \multicolumn{2}{|c|}{0.012} & \multicolumn{2}{|c|}{0.003} & \multicolumn{2}{|c|}{$<0.001$} & \multicolumn{2}{|c|}{$<0.001$} \\
\hline
\end{tabular}

Source: Compiled by author based on results from the Brazilian Disease Notification System (SINAN)/Ministry of Health.

There were significant reductions in PM mortality rates of 63.53\%, 70.33\%, 61.73\% and 69.49\% in Mid-West, Northeast, North and Southeast regions during P2 (Table 2). In the South region, there was a non-significant reduction in PM mortality rate of only $23.52 \%$ between pre and post-vaccine periods.

Table 2 - Mean PM mortality rates in under-5s for Brazil and regions, pre (M1) and post (M2) PCV-10 vaccine introduction.

\section{GENERAL}

\begin{tabular}{lccccccc}
\hline \multirow{2}{*}{ Comparison } & \multicolumn{2}{c}{$\mathbf{2 0 0 3 - 2 0 0 9}$} & \multicolumn{2}{c}{$\mathbf{2 0 1 1 - 2 0 1 7}$} & $\begin{array}{c}\text { Difference }= \\
\text { (M1-M2) }\end{array}$ & \% Reduction & $\begin{array}{c}\text { Comparison } \\
\text { p-value }\end{array}$ \\
\cline { 2 - 5 } Mean & SD & Mean & SD & & $\mathbf{0 . 0 0 1}$ \\
Northeast & 1.02 & 0.35 & 0.37 & 0.20 & 0.65 & 63.53 & $<\mathbf{0 . 0 0 1}^{\dagger}$ \\
North & 0.43 & 0.08 & 0.13 & 0.09 & 0.30 & 70.33 & $\mathbf{0 . 0 3 3}$ \\
Southeast & 0.40 & 0.26 & 0.15 & 0.09 & 0.24 & 61.73 & $<\mathbf{0 . 0 0 1}^{\dagger}$ \\
South & 1.40 & 0.27 & 0.43 & 0.14 & 0.97 & 69.49 & 0.147 \\
Brazil & 0.82 & 0.27 & 0.63 & 0.18 & 0.19 & 23.52 & $<\mathbf{0 . 0 0 1}^{\dagger}$ \\
\hline
\end{tabular}

$\mathrm{SD}=$ Standard deviation; ${ }^{\dagger}$ Significant reduction $(\mathrm{p}<0.05)$. Source: Compiled by author based on results collected from the Brazilian Disease Notification System (SINAN).

Data on PCV-10 vaccine coverage by region is presented in Table 3, revealing a heterogeneous distribution for the period spanning from 2011 to 2017. The lowest vaccine coverage rates occurred in the North and Northeast regions over the study period. In 2017 , however, vaccine coverage rates in all regions fell below the $95 \%$ minimum level recommended by the Ministry of Health. 
Table 3 - Distribution of PCV-10 vaccine coverage for Brazil and regions, by year (2011-2017).

\begin{tabular}{lcccccccc}
\hline REGION & $\mathbf{2 0 1 1}$ & $\mathbf{2 0 1 2}$ & $\mathbf{2 0 1 3}$ & $\mathbf{2 0 1 4}$ & $\mathbf{2 0 1 5}$ & $\mathbf{2 0 1 6}$ & $\mathbf{2 0 1 7}$ & Total \\
& & & & & & & & \\
\hline Mid-West & 87.40 & 91.49 & $101.60 *$ & $101.42 *$ & 92.76 & 104.59 & 93.18 & $\mathbf{9 6 . 1 7 *}$ \\
& & & & & & $*$ & & \\
Northeast & 74.67 & 86.67 & 90.27 & 89.60 & 93.29 & 92.16 & 89.58 & $\mathbf{8 7 . 9 5}$ \\
North & 59.41 & 77.07 & 79.66 & 76.56 & 75.00 & 85.80 & 83.80 & $\mathbf{7 6 . 8 4}$ \\
Southeast & 87.50 & 90.31 & $95.92 *$ & $97.67 *$ & $99.01 *$ & $96.93 *$ & 94.56 & $\mathbf{9 4 . 6 1}$ \\
South & $95.63 *$ & 94.29 & $100.66 *$ & $97.90 *$ & $98.44 *$ & $96.71 *$ & 92.06 & $\mathbf{9 6 . 5 2 *}$ \\
Brazil & $\mathbf{8 1 . 6 5}$ & $\mathbf{8 8 . 3 9}$ & $\mathbf{9 3 . 5 7}$ & $\mathbf{9 3 . 4 5}$ & $\mathbf{9 4 . 2 3}$ & $\mathbf{9 5 . 0 0 *}$ & $\mathbf{9 1 . 5 6}$ & $\mathbf{9 1 . 1 5}$ \\
\hline
\end{tabular}

Source: compiled by author based on results collected in Tabnet win 32 3.0, 2019. * 95\% vaccine coverage target attained.

\section{Discussion}

The number of PM notifications pre (P1 2003-2009) and post (P2 2011-2017) vaccination decreased from 448 to 121 cases, respectively, in the Northeast, from 143 to 51 in the North, 493 to 210 in the South, and from 223 to 74 in the Mid-West. During P1, the lowest hospitalizations for PM occurred in 2007, while for the post-vaccine period, greatest reductions occurred from 2013 to 2015, with a slightly higher number of cases notified in both 2016 and 2017.

Field research carried out in the interior of the Northeast by Medeiros (2019) showed that PCV-10 led to a reduction in hospitalizations. For example, admissions for pneumonia in $67.6 \%$ of cases pre-vaccination fell to $32.4 \%$ in the period after PCV-10 introduction, i.e. a post-vaccine reduction of 52.17\%. A study in Zambia (South Africa) also found declines in hospitalizations after introduction of PCV-10, reducing hospitalizations both for meningitis (71\%) and pneumonia (37\%), with a consequent decrease in treatment costs (Mpabalwani, et al, 2019). Similarly, to the above-cited studies, the international retrospective cohort study by Petousis-Harris et al, 2019 in New Zealand of children aged under 6 years with IPD also reported a decline in cases, particularly for pneumonia. Hirose et al. (2015), in a cross-sectional study in Paraná State of PM cases reported a $65.8 \%$ reduction in children under 5 after introduction of the vaccine.

In the present study, the number of notified cases of PM was reduced post-PCV10 for all regions of Brazil, with the decline in hospitalizations for PM confirming the consistency of the vaccination intervention. Over the period studied, there was a significant reduction in the number of PM cases and in incidence and mortality rates of PM per 100,000 inhabitants in the under-5s after inclusion of the PCV10 vaccine into the national immunization program. Irrespective of the type of PCV administered, a significant reduction in IPD rates was observed in the pediatric population (Mackenzie, et al., 2016).

The present study results mirror the findings of numerous other studies conducted in other locations worldwide, showing a reduction in the incidence of IPD, including PM, after introduction of pneumococcal conjugate vaccines.

Countries such as the USA, the England and Wales, Denmark, France, South Africa (Mackenzie, et al., 2016; Koelman, et al., 2019), Australia and Canada (Fitzwater, et al., 2012) have benefited from the effects of introduction of the PCV7 vaccine into child immunization programs. The introduction of PCV10 or PCV13 has also proven successful, promoting significant reductions in PDI rates in Asian countries, South Africa (Fitzwater, et al., 2012), Kenya, Denmark, England, Finland, France, Germany and other European countries (Mackenzie, et al., 2016), the USA, Canada, Uruguay, Argentina, Chile, Colombia, 
among others. The present analysis also showed a consistent reduction in mortality caused by PM, corroborating the findings of other studies by Boni-Cisse et al. (2015) on the Ivory Coast and by Imohl et al. (2015) in Germany.

Statistical treatment of mean rates of PM incidence in the under-5 age group revealed a decrease in mean and standard deviation of PM after introduction of the vaccine studied. A greater PM reduction was seen in the Mid-West region, possibly explained by the vaccine coverage in the region which attained a high level during the period following PCV10 introduction. Despite catering for a large population, the Primary Care (APS) system, via its Basic Health Units (UBS), provides an effective service though its vaccination clinics. The Northeast region, despite its low socioeconomic level, was pioneering in the implementation of the Family Health Program (PSF), now known as the Family Health Strategy (ESF) (Bousquat, et al, 2017), ranking second in PM reduction rates.

In all countries, particularly low-to-middle income nations, there is evidence that level of socioeconomic development and its spatial distribution, correlated with the health status of the population. PM still poses a threat owing to its high incidence and lethality, potentially causing sequelae and death in children under five years. Based on the spatial distribution of PM lethality and of HDI in the five geographic regions of Brazil, health care and economic, income and health-related factors influencing vaccine coverage of children were investigated.

During P1, PM lethality rate ranged from $27.23 \%$ to $38.93 \%$ in Brazil, where the Southeast region had both the highest lethality rate and HDI (0.678: medium HDI) in 2000 (Figure 2). According to the IBGE, the Southeast region remains the most populous and boasts one of the highest levels of economic development. Also for P1, the lethality rate in the Northeast region proved similar (38.29\%), yet this region has one of the lowest HDI (0.516: low) in Brazil.

Souza et al. (2012), in an epidemiological study carried out during a similar period to the present study, reported a lethality rate for bacterial meningitis of $27.3 \%$ in children under 5 , whereas the population study on PM by Traore et al. (2009) in Burkina Faso and Togo (Africa) found the much higher mortality rate of almost 50\%. The current study results showed that HDI, whether high or low, was not associated with lethality. The vaccine in use during P1 was PCV7, as was the case for many other countries during the period, including Italy, Canada, Japan and USA (McClure, et al., 2006; Loze, et al., 2017), at a high cost to each country.

The HDI of the different regions of Brazil was highly heterogeneous during P1 and P2, with disparities in income distribution, education and social inequality. These aspects impacted health of the population due to a lack of adequate systematized primary care for under-5s, making them vulnerable to several diseases, particularly those preventable by vaccination, leading to fewer referrals to secondary and tertiary health care services.

Lethality rates detected during P2 were higher in the Mid-West (48.53\%) and North (40.08\%) which, at the time, also had high HDI (0.757) and medium HDI (0.667), respectively. These were the only regions in which lethality rates associated with PM rose relative to P1. The lowest lethality rates for the two periods were recorded in the South region, at $27.23 \%$ in P1, declining slightly to 26.98\% in P2. For these same periods, the HDI of the South increased from medium (0.660) to high (0.757).

The Mid-West and North regions showed a significant reduction in PM, but with higher lethality rates for P2. The increased lethality in the North might have been attributed to the low vaccine coverage during the 2011-2017 period of only $76.84 \%$, falling well short of the $95 \%$ target for PCV10. Access difficulties due to the geographic area, particularly among rural populations, together with a lack of immunobiological materials, can limit the reach of vaccine coverage, where the North region has one of the lowest rates of health care service use (Garnelo, et al., 2018).

Investment in primary care reduces costs with secondary and tertiary care. During the period assessed, Brazil experienced a drop in gross domestic product (GDP) and cuts in government spending. These changes negatively impacted both health and education, although expenditure in these areas is on a par some other countries, where $46 \%$ of public spending is on health, compared to 51.28\% in Latin America and the Caribbean. In 2000-2014, total health expenditure rose to 8.3\% of GDP 
and per-capita health expenditure increased (Massuda, et al. 2018). Economic and human development, and health system complexity in terms of Health Regions can be assessed using the MHDI under the UN Development Programme (UNDP), which serves to assess inequalities. However, there is unequal distribution throughout Brazil (Duarte, et al., 2015).

According to Albuquerque et al. (2017), spending on primary care can be categorized for the five main regions in the country. The Southeast and South regions have a high socioeconomic development and higher quality health services, although these regions exhibit internal differences in inequality, possibly associated with HDI. The Mid-West and North areas have medium-level primary care services and high socioeconomic development, but service availability and complexity are low. Lastly, the Northeast has the lowest level of socioeconomic development and fewer hospital beds available.

The Southeast and Northeast regions are the most populous, with the Southeast having the largest contingent, on average 50\% more than the Northeast (Silva and Mezzarobba, 2018). The Southeast, on the other hand, has a mixed population and poor income distribution between rich and poor, often constituting a barrier to access. Duarte (2018) noted that $80 \%$ of the Brazilian population relies exclusively on the national health system (SUS) and that only a small proportion of the population are users of the private healthcare system.

It is noteworthy that PM mortality in under-5s decreased by $57.82 \%$ between the pre and post-PCV10 vaccine period in Brazil as a whole. This reduction was $70.33 \%$ in the Northeast region, possibly explained by the large number of Basic Health Units (UBS) in the region (Malta, et al., 2016). As outlined earlier, the Northeast region was pioneering in the implementation of Family Strategy Teams. Moreover, the quality of service supported by a larger number of vaccination clinics tends to increase vaccine coverage.

Although the introduction of the PCV10 has had a major impact in reducing rates of incidence and mortality attributed to PM across all regions of Brazil, PM cases remain high. This situation points to the need for exploring new prevention strategies, given that reducing morbidity-mortality from preventable diseases through immunization will only be possible if vaccine coverage remains high and consistent. This goal may prove difficult owing to the large contingent of the Brazilian population $(15 \%)$ living in rural areas, the geographic diversity of some regions, and socioeconomic inequalities in the country (IBGE, 2010).

The effectiveness of pneumococcal vaccines (PCV10 or PCV13) is widely recognized by surveillance agencies of many countries. A study by Soeters et al. (2020) in Burkina Faso, Africa, showed the impact of the PCV13 vaccine was high, reducing cases by $62 \%$. In a bid to cut costs, Italy explored the impact of switching from the PCV13 to the PCV10 vaccine, but continuing with the PCV13 proved more cost-effective, while Belgium saw an increase in 19A serotypes after changing the PCV, (Ansaldi, 2020).

In terms of impact of vaccinations, PCV10 has promoted a significant reduction in IPD and a dramatic reduction in the burden of PM in children. There are shortcomings in the free immunization provided in Brazil, evidenced by high lethality rates, low vaccination coverage in some regions of Brazil, with rates falling short of Ministry of Health targets, leading to higher burdens in primary and secondary care. Studies involving candidate pneumococcal vaccines incorporating a large number of serotypes are currently undergoing development so that new vaccines can improve the prevention of diseases caused by Streptococcus pneumoniae, such as the PCV-15 and PCV-24 vaccines (kwambana-Adams, et al., 2020; Ludwig, et al., 2020). However, the problem in hand does not center on switching from PCV10, but rather on improving conditions to improve the quality of the services offered, thereby reducing future diseases in children by attaining the target vaccination coverage recommended under the National Immunization Program. 


\section{Final Considerations}

The study results revealed a dramatic reduction in incidence and mortality rates of PM in children aged under 5. This reduction was consistent across all regions of Brazil. The residual rates of PM linked to the reemergence of non-vaccine serotypes creates the need to maintain surveillance policies able to provide sensitive monitoring of the epidemiological situation of meningitis in Brazil, allowing alternative strategies to be devised which can optimize this impact.

In spite of the improvements in HDI in Brazil during the study period, lethality rates remained high, with no clear tendency for decline in PM cases correlated with increased HDI in the country as a whole, suggesting that other factors play a more important role in determining these rates.

Some regions, particularly in the final years of the study, have shown a concerning decline in vaccine coverage rates which consistently fall short of the $95 \%$ level recommended by the Ministry of Health. This declines is set be further exacerbated by the lock-down measures implemented during the COVID-19 pandemic, highlighting the urgent need for strategies to restore vaccination coverage levels and avoid a recrudescence in cases and deaths associated with potentially preventable diseases.

However, there is a need for specific studies on the impact of PM. Most articles published focus on meningitis and pneumonia or IPD in general, and fail to report the specific impact of PCV10 by region, particularly the North of the country. Other aspects which should be determined include the quality of immunization of the PCV10 vaccine in children of the age studied, improved supply of inputs, qualified vaccinators in the primary health system, and more accurate epidemiological surveillance in the hospital networks, in an effort to reduce cases and diseases associated with PM.

\section{References}

Albuquerque, M. V., Viana, A. L. D., Lima, L. D., Ferreira, M. P., Fusaro, E. R., \& Iozzi, F. L. (2017). Desigualdades regionais na saúde: mudanças observadas no Brasil de 2000 a 2016. Ciência \& Saúde Coletiva, 22 (4), 1055-1064.

Ansaldi, F., Pugh, S., Amicizia, D., Di Virgilio, R., Trucchi, C., Orsi, A., et al. (2020). Estimating the Clinical and Economic Impact of Switching from the 13Valent Pneumococcal Conjugate Vaccine (PCV13) to the 10-Valent Pneumococcal Conjugate Vaccine (PCV10) in Italy. Pathogens, 9 (2), 76.

Barichello, T., Generoso, J. S., Collodel, A., Moreira, A. P., \& Almeida, S. M. (2012). Pathophysiology of acute meningitis caused by Streptococcus pneumoniae and adjunctive therapy approaches. Arquivos de Neuro-Psiquiatria, 60 (5), 366-372.

Boni-Cisse, C., Jarju, S., Bancroft, R. E., Lepri, N. A., Kone, H., Kofi, N., et al. (2015). Etiology of Bacterial Meningitis Among Children <5 Years Old in Côte d'Ivoire: Findings of Hospital-based Surveillance Before and After Pneumococcal Conjugate Vaccine Introduction. Clinical Infectious Diseases, 15;69 (2), 114-120.

Bousquat, A., Giovanella, L., Fausto, M. C. R., Fusaro, E. R., Mendonça, M. H. M., Gagno, J., et al. (2017). Tipologia da estrutura das unidades básicas de saúde brasileiras: os 5 R. Cadernos de Saúde Pública, 33 (8), 1-15.

Chao, F., You, D., Pedersen, J., Hug, L., \& Alkema, L. (2018). National and regional under-5 mortality rate by economic status for low-income and middleincome countries: a systematic assessment. Lancet Global Health, 6 (5), e535-e547.

Duarte, C. M. R., Pedroso, M. M., Bellido, J. G, Moreira, R. S., \& Viacava, F. (2015). Regionalização e desenvolvimento humano: uma proposta de tipologia de Regiões de Saúde no Brasil. Caderno de Saúde Pública, 31 (6), 1163-1174.

Duarte, E., Eble, L. J., \& Garcia, L. P. (2018). 30 anos do Sistema Único de Saúde. Epidemiologia e Serviços de Saúde, 27 (1), 1-2

Fitzwater, S. P., Chandran, A., Santosham, M., \& Johnson, H. L. (2012). The Worldwide Impact of the Seven-valent Pneumococcal Conjugate Vaccine. The Pediatric Infectious Disease Journal, 31 (5), 501-508.

Garnelo, L., Lima, J. G., Rocha, E. S. C., \& Herkrath, F. J. (2018). Acesso e cobertura da atenção primária à saúde para populações rurais e urbanas na região norte do Brasil. Saúde em Debate, 42 (1), 81-99.

Grando, I. M., Moraes, C., Flannery, B., Ramalho, W. M., Horta, M. A. P., Pinho, D. L. M., et al. (2015). Impact f 10-valent pneumococcal conjugate vaccine on pneumococcal meningitis in children up to two years of age in Brasil. Cadernos de Saúde Pública, 31 (2) $276-284$.

Hirose, T. E., Maluf, E. M. C. P., \& Rodrigues, C.O. (2015). Pneumococcal meningitis: epidemiological profile pre and post-introduction of the pneumococcal 10-valent conjugate vaccine. Jornal de Pediatria, 91 (2), 130-135.

Imohl, M., Moller, J., Reinert, R. R., Perniciaro, S., van der Linden, M., \& Aktas, O. (2015). Pneumococcal meningitis and vaccine effects in the era of conjugate vaccination: results of 20 years of nationwide surveillance in Germany. BMC Infectious Diseases, 15 (14), 61.

Instituto Brasileiro de Geografia e Estatística. IBGE. Censo 2010. IBGE; 2010. http://censo2010.ibge.gov.br/. 
Instituto Brasileiro de Geografia e Estatística. IBGE. Mapas. IBGE; 2019. https://www.mapas.ibge.gov.br.

Koelman, D. L. H., Brouwer, M. C., \& van den Beek, D. (2019). Targeting the complement system in bacterial meningitis. Brain, 142 (11), 3325-3337.

Kwambana-Adams, B. A., Mulholland, E. K., Satzke, C., \& ISPPD group. (2020). State-of-the-art in the pneumococcal field: Proceedings of the 11th International Symposium on Pneumococci and Pneumococcal Diseases (ISPPD-11). Pneumonia, 12 (2), 1-14, 5.

Lovera, D., Aranda, C., Duarte, M., Apodaca, S., Acuña, J., \& Arbo, A. (2011). Predicción de la mortalidad de la meningitis neumocóccica en niños. Pediatría (Asunción), 38 (2), 111-117.

Loze, P. M., Nasciben, L. B., Sartori, A. M. C., Itria, A., Novaes, H. M. D., \& de Soárez, P. C. (2017). Vaccines are different: A systematic review of budget impact analyses of vaccines. Vaccine, 15;35 (21), 2781-2793.

Ludwig, G., Garcia-Garcia, S., Lanaspa, M., Ciruela, P., Esteva, C., Sevilla, M. F, et al. (2020). Serotype and clonal distribution dynamics of invasive pneumococcal strains after PCV13 introduction (2011-2016): Surveillance data from 23 sites in Catalonia, Spain. Plos One, 15 (2), 1-16, 6.

Malta, D. C., Santos, M. A. S., Stopa, S. R., Vieira, J. E. B., Melo, E. A., \& Reis, A. A. C. (2016). A Cobertura da Estratégia de Saúde da Família (ESF) no Brasil, segundo a Pesquisa Nacional de Saúde, 2013. Ciência e Saúde Coletiva, 2 (21), 327-338.

Massuda, A., Hone, T., Leles, F. A. G., de Castro, M. C., \& Atun, R. (2018). The Brazilian health system at crossroads: progress, crisis and resilience. BMJ Global Health, 3;3 (4), e000829.

McClure, C. A., Ford, M. W., Wilson, J. B., \& Aramini, J. J. (2006). Pneumococcal conjugate vaccination in Canadian infants and children younger than five years of age: Recommendations and expected benefits. Canadian Journal of Infectious Diseases and Medical Microbiology, 17 (1), $19-26$.

Medeiros, H. R. L. (2019). Impacto da vacina pneumocócica conjugada 10-valente (PCV10), na hospitalização por pneumonia no sertão da Paraíba. Dissertação (Mestrado). São Paulo: Faculdade de Ciências Médicas da Santa Casa de São Paulo.

Ministério da Saúde. Secretaria de Vigilância em Saúde. Fundação Oswaldo Cruz. Introdução à Estatística Espacial para a Saúde Pública. Simone, M., Santos, W., Souza, V. organizadores: Ministério da Saúde; 2007. http://www.escoladesaude.pr.gov.br/arquivos/File/TEXTOS_CURSO_ VIGILANCIA/capacitacao_e_atualizacao_em_geoprocessamento_em_saude_3.pdf

Moraes, C., Portela, C. O., Alves, R. V., Ribeiro, I. G., Costa, M., Alves, R. M. S., et al. Meningite Pneumocócica por Streptococcus pneumoniae (pneumococo) Bol Epidemiol [Internet]. 2019 set [21/01/2021]; 50(n.esp.):48-50. (Número especial: Vigilância em Saúde no Brasil 2003|2009: da criação da Secretaria de Vigilância em Saúde aos dias atuais). http://www.saude.gov.br/

Moreira, M., Cintra, O., Harriague, J., Hausdorff, W. P., \& Hoet, B. (2016). Impact of the introduction of the pneumococcal conjugate vaccine in the Brazilian routine childhood national immunization program. Vaccine, 34(25), 2766-2778.

Mpabalwani, E. M., Lukwesa-Musyani, C, Imamba, A, Nakazwe, R., Matapo, B., Muzongwe, C. M., et al. (2019). Declines in pneumonia and meningitis hospitalizations in children under 5 years of age after introduction of 10-valent pneumococcal conjugate vaccine in Zambia, 2010-2016. Clinical Infectious Diseases, 2 (66), 1-8.

Nhantumbo, A. A., Weldegebriel, G., Katsande, R., Gouveia, L., Comé, C. E., et al. (2017). Surveillance of impact of PCV-10 vaccine on pneumococcal meningitis in Mozambique, 2013 - 2015. Plos One, 12 (6), 1-17, 12.

Oliveira, D. N. (2017). Distribuição de meningite pneumocócica no Brasil e distribuição e análise espacial de meningite pneumocócica no estado de São Paulo, no período pré (2005 a 2009) e pós-vacinação infantil (2011 a 2013). Tese (Doutorado). São Paulo. Faculdade de Medicina da Universidade de São Paulo.

Omwono, J., \& Silundika, P. S. (2020). Interventions for Reducing Infant Mortality in Developing Countries: A Literature Review [Tese de Bacharelado]. JAMK University of Applied Sciences.

Petousis-Harris, H., Howe, A. S., Paynter, J., Turner, N., \& Griffin, J. (2019). Pneumococcal Conjugate Vaccines Turning the Tide on Inequity: A Retrospective Cohort Study of New Zealand Children Born 2006-2015. Clinical Infectious Diseases, 15;68 (5), 818-826.

Rouquayrol, M. Z., \& Gurgel, M. Rouquayrol. (2013). Epidemiologia e Saúde: Medbook.

Silva, H. C. G., \& Mezarobba, N. (2018). Meningite no Brasil em 2015: o panorama da atualidade. Arquivos Catarinenses de Medicina, 47 (1), $34-46$.

Soeters, H. M., Kambiré, D., Sawadogo, G., Ouédraogo-Traoré, R., Bicaba, B., Medh, I., et al. Evaluation of pneumococcal meningitis clusters in Burkina Faso and implications for potential reactive vaccination. Vaccine, 38 (35), 5726-5733.

Souza, S. F., Costa, M. C. N., Paim, J. S., Natividade, M. S., Pereira, S. M., Andrade, M. S., et al. (2012). Meningites bacterianas e condições de vida. Revista da Sociedade Brasileira de Medicina Tropical, 45 (3), 323-328.

Traore, Y., Tameklo, T. A., Njanpop-Lafourcade, B., Lourd, M., Yaro, S., Niamba, D., et al. (2009). Incidence, seasonality, age distribution, and mortality of pneumococcal meningitis in Burkina Faso and Togo. Clinical Infectious Diseases, 48 (S), S181-S189.

UNICEF. (2012). Committing to child survival: a promise renewed. Unicef’s Division of Policy and Strategy., 1-44.

Varghese, L., Talbot, L., Govender, A., Zhang, X-H., \& Mungall, B. C. (2018). A cost-effectiveness analysis of the 10-valent pneumococcal non-typeable haemophilus influenzae Protein D conjugate vaccine (PHiD-CV) compared to the 13 -valent pneumococcal conjugate vaccine (PCV13) for universal mass vaccination implementation in New Zealand. Applied Health Economics and Health Policy, 16 (3), 331-345.

Vieira, I., \& Kupek, E. (2016). Impact of PCV10 pneumococcal vaccine on mortality from pneumonia in children less than one year of age in Santa Catarina State, Brazil. Cadernos de Saúde Pública, 32 (3), 1:11. 
Research, Society and Development, v. 10, n. 2, e21310212438, 2021 (CC BY 4.0) | ISSN 2525-3409 | DOI: http://dx.doi.org/10.33448/rsd-v10i2.12438

World Health Organization (WHO). (2018). Vaccination Coverage Cluster Survey: Reference Manual. WHO/IVB/18.09; Geneva, 1-234. 